\title{
Reformation and Development Prospect of the International Tax Regime
}

\author{
Zhang Zheng ${ }^{1}$ \\ ${ }^{1}$ Xi'an International University, 710077
}

Keywords: international tax; regime; reformation; development prospect

\begin{abstract}
As hundreds years of development, the international tax regime goes through 100-years reformation and its future development will directly influences the international investment and economy. From a view of point of the international economy, the constitution, reformation, and the development of the international tax regime all have special regular pattern. This thesis sets forth the current structure and the definition of the international tax regime first, then, analyses its reformation and development progress, and imperfection. At last, it looks into the future of the prospects for development of the international tax regime.
\end{abstract}

As the rapid development of globalization, modernization, and informatization, the situation of international economy is constantly changing and adjusting. The international tax regime as a dynamic element drives international economy and politics goes to forward rapidly ${ }^{[1]}$. On the view of the international economic development, the development and reformation of the international tax regime ties closely to the international investment and economy. Although international tax regime is increasingly perfect after many years development, and it is fits the changed age and demand of economy development step by step, but it still has some obvious defects, has more spaces to develop and reform as well. Nowadays, the proportions of the developing countries become more and more in the modern world. On the view of the proportion of the developing economic entity, the new international tax regime will come into being in the trend of the development of every country.

\section{Current Definition of the International Tax Regime}

The definition of international tax regime is not unified at this time, in a manner of speaking, it is a mechanism that is exist in fact, is an international conception for developing international economy and tax demands. What's more, it is fiercely argumentative in academia. In some one's opinion, tax regime of every country in the international market is isolated, is not like some regulatory international conventions such as the WTO, the IMF,etc. So to speak, the international tax regime is just a conception, not a actual existence; In the others opinion, although tax regime of every country and the bilateral international tax rules have some difference, but it contains the some international rules, so the international regime which is being understood and known in our daily life is existed ${ }^{[2]}$. As a result, international tax regime is existed. From the late of the $19^{\text {th }}$ century, On the view of the development of international economy, multinational economy is constantly progressive, the cooperation of the international tax is in progress far and wide between different countries, so, any country would not hold in esteem the tax system of their own country without considering other countries tax system, and this also shows that tax system is a kind of patterned behavior and it is restrained by the international behavior. So in my opinion, international tax regime is existed actually.

\section{Constitution of the International Tax Regime}

The international tax regime is a kind of international agreement that is not only a international regime which is embodied in tax field, but also signed by some countries for restraining and regulating their tax behaviors. At the some time, the contents of the agreement restrain the tax behaviors of those countries. The international tax regime is consist of the united coordinating 
organizations and relative standards which is concretely promised by different counties, it can regulate the organization which is highly organized, but it is not suitable for the organization which is loosely and freely organized. The constitution of international tax regime is basically similar with the explanation which is brought out by the famous American economist Douglass C. North on system constitution. In other words, the constitution of system, includes two forms----formal restraint and informal restraint, is not only a kind of reasonable arrangement for coordinating the competitive and cooperative relations between organizations and individuals, but also a kind of specially means to regulate the behavior ${ }^{[3]}$. On the view of constitution of the main part, international tax system has visible feature, the contents of the visible system not only contains international multilateral, bilateral, regional tax agreement, but also principles, regulations, rules, procedures. On the view of invisible restrict regime, the constitution of invisible tax system has close relativity to the visible tax system, it is principle part of visible system in fact. However, comparing with the contents of visible regime, it is without exaggeration that the key part of the institution of international tax regime is the principle part of invisible system which is steadier and more lasting. If this part would change, it is to say that the international tax system will changed totally; but if the regulations, rules, and procedures of visible system is changed, so to speak, some contents is changed, it means the key part and the other part would change more or less.

\section{Reformation and Development of International Tax Regime}

International tax regime comes from the development of economy and tax demand of every country. From the middle to the late of the 19th century, the international tax regime comes into being. At that time, the economy of every country grew rapidly with fiercely turbulent trend. Every country begun to tax incomes under the influence of The War One, income tax system begun to be popular $^{[4]}$. After then, the public sector grew bigger and bigger, the tax level of every country was raised, cross-border income was highlighted by many countries. Under this situation, the quantity of transnational enterprises increased rapidly, the developed countries begun to reduce or remit tax under the push of the command of international trade. However, it didn't lead a satisfying result by unilateral tax reduce or remit, so cooperative international tax system is badly needed. In this way, the international tax regime begun to set sail. From 1920s to the War Two, it is the initial establishing stage of international tax regime. The international chamber of commerce called on "abolish bilateral-taxed evil”, and then, international tax regime was established step by step. By and by the League of Nations founded an expert panel to specialize in researching tax regime. After many years development, it came to maturation period, the Banking and Finance Committee which took charge for international tax affairs until 1954 was established. Then, the international tax regime transformed to Organization for Economic Co-operation and Development (OECD), it made reformation on the basis of League of Nations' tax agreement exemplification and carried out united tax agreement exemplification. After 1990s, the international tax regime came into perfect development stage, OECD revised version of the international tax agreement and made "dynamic mould". After this, OECD revised the exemplification every three years, and on the basis of this, added CFC principle, updated pricing rules, improved and perfected itself, solved the problems such as harmful tax competition, etc ${ }^{[5]}$.

\section{Defects of Current International Tax Regime}

The current international tax regime has some defects as below: (1)No mandatory international conventions. Because the international tax regime is established on the international system that is soft system, and this regime is set up and revised by the western countries basically, it is more suitable for the economic system of western countries. On the view of the idea of this regime, the rules and regulations of this regime is branded by western countries' idea, full of the conception of freedom. (2) "Soft-restraint” feature is outstanding. Tax is a basic national policy for coordinating the growth of economy, but the international tax regime indicates the sovereignty of a country. The current international tax system is designed for protecting the tax sovereign rights first. Therefore, 
for economic reasons, the multilateral process in tax field is weak, not outstanding enough, and even far weaker than their own economic field of some countries ${ }^{[5]}$. However, the current system still restrains and regulates the tax behavior of every country, influences the making of tax law of every country and bilateral agreement according to the principles and regulations in some extent. (3)International tax dispute. In current international tax regime environment, the main method to solve dispute is bilateral consultation according to the agreement and model exemplification spirit. This method is lack of united standard and specifications, so that lots of international tax disputes can not be solved, it shows the imperfection of current international tax system. What's more, lots of bilateral tax agreement makes a prominent problem that there is no a united agreement, but this brings some conveniences to international for tax avoidance so that lots of transnational enterprises trends to evade tax.

\section{Developing Prospect of International Tax Regime}

There is enough room to develop and perfect the problems that exist in current international tax regime, and the more perfect regime will be set up, it will bring and drive the most countries to make progress, then the international economy will come into a new stage. In the future, how to carry forward "Base Erosion and Profit Shifting (BEPS)" becomes the main issue during the development and perfection of the international tax regime. In 2012, BEPS issue has been wholly researched and discussed. it is believed there will be a breakthrough very soon on this issue. In the next place, promoting the information open and forming tax information exchange space between different places, this program could solve the tax avoidance problem effectively. Tax avoidance can not exist without information sharing and administrative supporting. In former < tax information exchange agreement model>,the rules that information exchange is only in progress when it is requested must be reformed and revised, or it is hard to set up a international restraint regime. "BEPS action projects" was officially launched in 2013. It means that the international tax regime has come into a new stage. After 2016, the key work of international tax reform is build consensus and carrying out all the achievement. In the future, we should enlarge the influence and extent of achievement carrying out, raise the extent of joining, attract more countries to join the regime, construct and perfect the regime, update and perfect the new rules and regime. From the proportion of the developing economies in the international investment and economy, the new international tax system must be come into being and perfect in the economic development trend of every country.

\section{Conclusion}

Considering from the views of framework and feature, the current international tax regime is fit for the development of many countries' economy. Because of defects of this regime, it is easily to find that there are large spaces for development of the regime, the regime will be perfected step by step as well. On the view of international situation, the position of the developing countries is becoming higher and higher, they will change the power situation in the international tax field, in other words, the developing countries will play an important role and make great contributions to the international tax system as their economy growth. The central of the international economy is moving to the east world now, some countries, such as China that has strong national power and economic strength, they hold a higher proportion of the international investment, and the proportion will be become bigger and bigger. Correspondingly, the scale and quantity of the transnational corporations of these countries is increasing, as their benefit is increasing in the international tax field, they will call for generating the new international tax rules, and their request will be powerful and will be respected. At last, their own benefit command will change to a part of the international rules. Under this situation and prospect, the new international tax system will come into being. 


\section{Reference}

[1] Shi Yi, Research on the influence of technological innovation tax encouraging policy of China [J]. Forum on Science and Technology in China, 2017, (03):171-179.

[2] Wang Wenjing, First exploration on Cross-border taxation issue under the strategy of "the Belt and Road"---- Comparison on the basis of income tax law of company and the International Taxation Agreement[J]. Financial Law, 2016, (02):20-30.

[3] Cao Mingxing, Liu Qichao, Three international tax planning methods of cross border income of the "go global strategy" enterprise----Observation on the basis of countries around "the Belt and Road”[J].Reform of Economy Systerm, 2016,(01):104-111.

[4] Liu Xinying, Song Yan, Japan, South Korea: The participator of the draft of the international tax rules, and the navigator of the application [J]. International Taxation In China, 2016,(01):17-21.

[5] Liao Tizhong, The international tax cooperation is under the sunshine----unscrambling the achievement of the action projects of BEPS[J]. International Taxation in China, 2015, (10):6-11.

[6] $\mathrm{Du} \mathrm{Li}$, The Summarization of the Academic symposium on China how to deal with the international tax issues" free trade zone and the international tax problems of 'Post-BEPS era'" at the capital export times[J]..World Economic Papers, 2015, (03):118-120. 